\title{
Perempuan Petani, Akuisisi dan Perjuangan Atas Tanah (Studi Kasus Perempuan Petani Desa Sumurgeneng, Kabupaten Tuban)
}

\author{
Ika Setya Yuni Astuti ${ }^{1}$, Donna Asteria ${ }^{2}$ \\ Program Studi Kajian Gender Universitas Indonesia ${ }^{1,2}$ \\ Email:ikasetyay@gmail.com ${ }^{1 *}$ \\ ${ }^{*}$ corresponding author
}

\begin{abstract}
Abstrak
Perlawanan perempuan merupakan isu yang menarik dalam konteks penolakan pembangunan tambang. Perempuan tidak hanya menghadapi ancaman kehilangan mata pencaharian, tetapi juga sumber penghidupan mereka. Perjuangan perempuan atas tanah didasari oleh identitas mereka sebagai petani dan naluri untuk mempertahankan ruang hidupnya. Tujuan penelitian ini untuk memahami perlawanan dan kompleksitas kehidupan perempuan petani dalam usaha mempertahankan tanah sebagai sumber penghidupannya, serta merefleksikan bagaimana terjadinya perlawanan yang dilakukan perempuan petani desa Sumurgeneng atas akuisisi lahan pertanian yang dilakukan oleh PT. Pertamina Rosneft melalui kajian feminis dengan menggunakan teori ekologi politik feminis untuk menelusuri serangkaian perlawanan dan keterkaitan antara relasi kuasa yang tidak seimbang dengan usaha mempertahankan sumber penghidupan yang dialami oleh perempuan petani di Sumurgeneng. Artikel ini menggunakan penelitian berperspektif perempuan dengan pendekatan kualitatif. Teknik pengumpulan data dilakukan dengan wawancara dan observasi lapangan serta tinjauan pada penelitian-penelitian terdahulu untuk menelusuri bagaimana perlawanan perempuan petani dan bagaimana relasi perempuan terhadap sumber-sumber penghidupan telah mempengaruhi gerakan perlawanan mereka.
\end{abstract}

Kata kunci : perempuan petani; akuisisi; perlawanan; penghidupan; gerakan

\section{Women Farmers, Acquisition and Struggle for Land (Case Study of Women Farmers in Sumurgeneng Village, Tuban Regency)}

\begin{abstract}
Women's resistance is an interesting issue in the context of the rejection of mining development. Women not only face the threat of losing their livelihood but also their source of livelihood. Women's struggle for land is based on their identity as farmers and the instinct to defend their living space. The purpose of this study is to understand the resistance and the complexity of the lives of women farmers to defend the land as a source of livelihood and to reflect on how the resistance by women farmers in Sumurgeneng village to the acquisition of agricultural land by PT. Pertamina Rosneft through a feminist study using feminist political ecology theory to explore a series of resistances and links between unbalanced power relations and efforts to maintain the livelihoods experienced by women farmers in Sumurgeneng. This article uses women's prospective research with a qualitative approach. Data collection techniques were carried out using interviews and field observations as well as reviews of previous studies to explore how the
\end{abstract}


resistance of women farmers and how women's relations to sources of livelihood had influenced their resistance movement.

Keywords : women farmer; acquisition; resistance; livelihood; movement

\section{LATAR BELAKANG}

Kerjasama antara PT. Pertamina Indonesia dan Rosneft Oil Company untuk pengembangan lokasi kilang minyak telah mencapai titik kesepakatan. Pada awal tahun 2019 lalu PT. Pertamina menjelaskan kepada publik tentang rencana pengembangan kilang minyak yang bertempat di Kecamatan Jenu, Kabupaten Tuban. Rencana PT. Pertamina membangun sebuah kilang minyak besar agar mampu menghasilkan minyak bumi dengan angka kumulatif lebih dari 1,5 juta barel per hari. Hal ini menyusul adanya data yang dihimpun dari Project Coordinator GRR Tuban dari Pertamina yang menyatakan sejak 2010 produksi minyak bumi Indonesia mengalami defisit yang signifikan. PT. Pertamina untuk memenuhi permintaan minyak bumi memutuskan untuk membangun pertambangan kilang minyak skala besar dan melibatkan perusahaan pengolahan minyak dari luar negeri yang terpilih yaitu Rosneft Oil Company Rusia sebagai mitra kerja dan bergabung menjadi PT. Pertamina Rosneft.

Kementrian Luar Negeri juga menyatakan kilang minyak di Tuban diperkirakan akan memiliki kapasitas produksi sebesar 300.000 barel per hari dengan total lahan yang dibutuhkan kurang lebih 700 hektar. Syahrial Mukhtar, Sekretaris PT Pertamina menyatakan dalam wawancaranya bersama media CNBC Indonesia 6 Februari 2019, pemerintah daerah telah memiliki sekitar 400 hektar lahan kosong dan membutuhkan 300 hektar lahan lagi untuk memperluas area pembangunan. Oleh karena itu agar permintaan kapasitas lahan terpenuhi, PT. Pertamina membutuhkan lahan kosong di beberapa desa di kecamatan Jenu. Namun permasalahannya adalah lahan yang dibutuhkan Pertamina tersebut merupakan lahan yang saat ini ditempati oleh warga termasuk Desa Sumurgeneng yang artinya jika mereka ingin menggunakan lahan tersebut maka warga harus meninggalkan lokasi tersebut agar dapat digunakan oleh PT. Pertamina Rosneft.

Warga Desa Sumurgeneng yang mendiami wilayah tersebut dengan tegas menolak permintaan PT. Pertamina. Mereka telah menghabiskan waktu selama beberapa generasi untuk hidup dan membangun keluarga disana. Bagi warga, Sumurgeneng tidak hanya sekedar wilayah untuk ditinggali. Sumurgeneng memiliki nilai historis yang mendalam terutama bagi para perempuan yang menggantungkan hidupnya dengan memanfaatkan sumber alam yang terdapat di Sumurgeneng. Mereka mencuci, memasak, bertani atau menjadi buruh tani dengan mengandalkan sumber alam yang ada disana, dengan kata lain Sumurgeneng merupakan ruang hidup sekaligus sumber penghidupan bagi warga disana.

Petani Sumurgeneng memahami betul arti penting tanah bagi mereka. Mereka secara tegas menolak surat edaran yang mengundang mereka hadir dalam diskusi publik yang diadakan oleh PT. Pertamina terkait penjualan lahan. Bagi mereka, tindakan sepihak PT. Pertamina juga telah memicu kemarahan warga desa. PT. Pertamina tanpa melakukan koordinasi terlebih dahulu, namun secara tiba-tiba mengeluarkan surat edaran penetapan lokasi yang berisi daftar wilayah beserta lahan yang dibutuhkan untuk kepentingan pembangunan. Akibatnya, warga desa Sumurgeneng sepakat untuk menyatakan tindakan yang dilakukan PT. Pertamina telah melanggar hukum dan menyatakan untuk tidak mengijinkan aktivitas apapun yang dilakukan perusahaan di 
wilayah mereka. Warga Sumurgeneng yang didominasi oleh petani kemudian menyusun perlawanan berupa unjuk rasa dan aksi protes kepada pemerintah setempat untuk menunjukkan ketegasan atas penolakan mereka.

Kasus penolakan dan perlawanan masyarakat lokal terhadap aktivitas pertambangan di Indonesia sebenarnya telah lama terjadi dan selalu mengalami peningkatan intensitas, terlebih setelah reformasi politik 1998 (Prayogo, 2008:4). Demokratisasi yang tercipta pasca reformasi adalah wujud perubahan politik yang menjadi jalan bagi lahirnya berbagai perlawanan terhadap industri tambang di Indonesia. Motif perlawanan yang dilakukan masyarakat lokal pun beragam, termasuk ekonomi, lingkungan, sosial hingga politik. Konteks budaya yang berbeda antar wilayah di Indonesia juga turut menjadi faktor terjadinya perlawanan. Cara dan bentuk penolakan yang dilakukan pun dapat menjadi berbeda antara satu dengan daerah lainnya. Meskipun studi mengenai kasus sengketa lahan sudah banyak dilakukan, namun tiap daerah memiliki ragam kasus yang berbeda sehingga perlu dilakukan penelitian lebih mendalam untuk melihat pola resistensi, konflik atau perlawanan masyarakat lokal terhadap keberadaan dan praktik pertambangan.

Beberapa studi terdahulu mengenai perlawanan pada industri pertambangan juga terjadi di berbagai daerah di Indonesia (Kurniawan, 2013; Prayogo, 2008; Regus, 2008). Titik utama kasus ini umumnya melihat konflik kepentingan sebagai penyebab utama lahirnya resistensi atau konflik tambang. Melalui kasus resistensi dan persistensi di desa Bonto Katute, Kabupaten Sinjai, Kurniawan (2013) menunjukkan bahwa perbedaan kepentingan dan pemahaman mengenai pertambangan yang ada di daerah tersebut melahirkan dua kelompok dalam masyarakat, yaitu kelompok yang resisten (menolak) karena menganggap bahwa proses pertambangan menyebabkan kerusakan lingkungan dan perubahan sosial budaya serta berbagai dampak negatif lainnya. Kelompok persisten (mendukung) yang berasal dari kalangan pemerintah dan jajarannya mendukung proses pertambangan ini karena menurut mereka pertambangan mendorong kemajuan ekonomi (Fringka, 2015).

Perempuan petani juga mengambil tempat yang cukup strategis dalam perlawanan petani desa Sumurgeneng. Mereka terlibat aktif dalam setiap aksi. Bagi mereka, memperjuangkan tanah Sumurgeneng seperti halnya memperjuangkan nyawa, karena di Sumurgeneng inilah ruang hidup mereka terbentuk dan di tanah Sumurgeneng ini mereka menggantungkan hidupnya. Ruang dan wilayah merupakan bagian penting dalam kehidupan petani. Merujuk pada konsep ruang hidup dan penghidupan perspektif gender Massey (1994) melalui karya Kerangka Analisis Ruang Hidup dan Penghidupan dg Perspektif Kesetaraan Gender dan Inklusi Sosial (2019) yang diterbitkan oleh The Samdhana Institute juga menyatakan jika ruang dan wilayah merupakan bagian penting dalam kehidupan perempuan. Ketika wilayah di mana perempuan bergantung hidup dirampas untuk dieksploitasi alamnya dan atau dihancurkan untuk diubah kegunaannya, perempuan akan menghadapi berbagai bentuk ketidakadilan, termasuk ketidakadilan gender, dan berbagai masalah lain yang muncul akibat kerusakan sosio-ekologis yang terjadi. Selain itu, dampak yang berlanjut adalah kemiskinan berkepanjangan. Dengan demikian, perempuan yang dirampas dan atau dihancurkan wilayah tempat ia bergantung hidup tidak hanya kehilangan tanah dan wilayah tetapi lebih jauh lagi ia kehilangan ruang hidupnya.

Ruang hidup para perempuan petani Sumurgeneng tidak hanya sebatas lahan pertanian. Lebih dari itu mereka juga menggantungkan diri dengan sumber alam di

$$
\text { Jurnal Sosiologi Pendidikan Humanis } 185 \text { | } 197
$$


Sumurgeneng. Mereka memanfaatkan air untuk mencuci, memasak, minum dan kebutuhan sehari-hari lainnya. Menurut pengakuan Mulan, Sumurgeneng merupakan daerah yang produktif. Lahan mereka dapat ditanami berbagai jenis tanaman pertanian bahkan warga Sumurgeneng telah terbiasa memenuhi kebutuhan sehari-hari dengan saling menukar hasil alam. Sehingga adanya pembangunan kilang tentu membuat mereka resah akan kelangsungan hidupnya di masa depan.

Seperti yang telah diketahui, pembangunan tambang tentu menyisakan berbagai macam persoalan, terutama limbah. Menurut jurnal Lemigas yang ditulis oleh Zulkifliani (Pusat Penelitian dan Pengembangan Teknologi Minyak dan Gas Bumi "LEMIGAS", 2017) kilang minyak sebagai pengolah dasar yang menghasilkan bahan bakar memiliki, material sisa dalam bentuk limbah padat, cair, dan gas yang dapat mencemari tanah, air, atau udara. Pencemaran tanah oleh limbah minyak seringkali ditemukan di area kilang minyak yang berasal dari tumpahan atau kebocoran pipa saat pengolahan, transportasi dari tanker ke unit pengolahan atau tangki penimbunan, dan ceceran sewaktu pembersihan tangki (tank cleaning). Tumpahan minyak tersebut akan mengkontaminasi air yang terkandung dalam tanah dan merubah warna air.

Bambang Yudono dalam tulisannya Eksplorasi Bakteria indigen Pendegradasi Limbah Minyak Bumi di Wilayah PT Pertamina UBEP Limau Muara Enim (2013) menyebutkan bahwa minyak yang merembes ke dalam tanah dapat menyebabkan tertutupnya suplai oksigen dan meracuni mikro organisme tanah sehingga mengakibatkan kematian mikroorganisme. Lebih lanjut, tumpahan minyak dapat mencemari tanah dan perairan hingga ke wilayah sub-surface dan lapisan aquifer air tanah.

Berdasarkan penuturan salah satu narasumber perempuan petani, lokasi utama pembangunan kilang minyak berada di tengah pemukiman warga di enam desa. Wilayah Sumurgeneng berada tepat pada lokasi yang akan dibangun dapur untuk tempat memasak minyak. Area kilang terdiri dari beberapa wilayah yang terbagi atas dapur, ruang penyimpanan sebelum diolah hingga ruang penyimpanan siap kirim. Jika dalam peta lokasi Sumurgeneng termasuk dalam area dapur, maka potensi warga Sumurgeneng terkontaminasi limbah hasil pengolahan minyak semakin besar. Tidak hanya berdampak pada tanah dan air tetapi juga udara yang sehari-hari dihirup oleh warga. Dengan demikian ruang aman untuk warga agar terhindar dari bahaya dan dampak kilang minyak hampir tidak ada.

Bagi petani Sumurgeneng sangat mustahil untuk hidup satu atap dengan pertambangan. Sekat antara tambang dan rumah warga hanya berbeda satu tembok. Itu berarti ketika tambang sedang memproses atau memasak minyak, maka asap yang dihasilkan akan langsung terhirup oleh warga. Limbah pembuangan dari produksi minyak selain berbahaya bagi lingkungan, juga berbahaya bagi kesehatan. Limbah minyak yang terserap dalam tanah akan merusak sumber air dan ekosistem yang ada didalamnya. Jika air rusak dan tercemar maka proses produksi dan konsumsi warga Sumurgeneng akan terganggu dan terhenti total.

Disinilah peran perlawanan itu tampak. Para petani merasa tidak ada satupun manfaat yang akan mereka dapatkan dari pembangunan kilang. Sebagaimana yang kita ketahui lahan produktif pangan di pulau Jawa setiap tahunnya menurun drastis. Berdasarkan catatan Dinas Pertanian Jatim, penyusutan lahan produktif hingga 2019 terus mengalami peningkatan. Saat ini saja, luas lahan produktif di Jatim sekitar 1.214.909 hektar. Lebih lanjut pada 2016 Badan Pusat Statistik (BPS) Jawa Timur 
mencatat sekitar 4.400 hektar lahan beralih fungsi dalam kurun waktu empat tahun, artinya ada sekitar 1.100 hektar lahan per tahun yang hilang. Artinya, ada berapa petani yang terancam kehilangan pekerjaannya? Dan jika seandainya mereka dialihkan menjadi buruh, ada berapa banyak petani perempuan yang dapat diserap tenaga kerjanya.

Dalam situasi seperti ini tidak menutup kemungkinan akan terjadi perubahan struktur kepemilikan lahan hingga relasi produksi. Pembangunan kilang minyak yang dilakukan dengan perampasan lahan pertanian telah memaksa petani kehilangan penghidupannya (livelihood). Alat produksi yang berupa tanah telah dialihfungsikan menjadi pertambangan. Kehilangan alat produksi, menjadikan mereka beralih kerja menjadi pekerja rentan. Jika merujuk pada Habibi (2016) dengan tesisnya yang dibukukan berjudul 'Surplus Pekerja di Kapitalisme Pinggiran.' kondisi memicu terjadinya surplus populasi relatif arena tanah hilang, relasi produksi berubah hingga pada satu titik akan menjadi pekerja rentan.

Penelitian ini sejatinya untuk menelusuri bagaimana posisi perempuan petani dalam usaha mempertahankan sumber penghidupan turut mempengaruhi perlawanan mereka, serta untuk menggali lebih dalam pengalaman perempuan petani dalam menghadapi dampak dari pembangunan kilang minyak. Penelitian ini secara signifikan juga berguna untuk menambah referensi kajian politik untuk dielaborasi dengan perspektif feminis yakni memberi masukan bagaimana menelusuri posisi dan relasi perempuan petani dalam sumber penghidupan. Secara khusus, penelitian ini juga akan memberikan sumbangsih pada perkembangan konsep ekologi politik feminis yang secara khusus membahas lahan sebagai sumber penghidupan yang dikaitkan dengan posisi dan relasi perempuan petani ditengah masyarakat.

Sejumlah penelitian terdahulu telah banyak membahas mengenai isu perlawanan masyarakat dan perjuangan mempertahankan tanah salah satunya adalah penelitian yang saya dapatkan dari The Journal of Peasant Studies yang dilakukan oleh Bina Agarwal dengan judul Gender, Resistance and Land: Interlinked Struggles Over Resources and Meanings in South Asia (2008) yang membahas mengenai sifat perlawanan perempuan terhadap ketidakadilan gender dalam distribusi sumber daya dan representasi ideologis. Agarwal (2008) berpendapat bahwa untuk memahami bagaimana perempuan memandang ketidakadilan perlu ini memperhitungkan bahwa mereka tidak hanya melakukan protes terbuka tetapi juga melalui perlawanan rahasia. Pada saat yang sama secara signifikan mampu mengubah struktur perlawanan yang awalnya 'individu-terselubung' bergerak menjadi resistensi 'kelompok-terbuka' (terorganisir dan kolektif).

Agarwal (2008) kemudian merangkum masalah-masalah terutama yang berkaitan dengan konteks perjuangan perempuan dalam memperjuangkan hak tanah dan kesetaraan gender di Asia Selatan. Meskipun secara historis perempuan Asia Selatan telah menjadi tokoh penting dalam gerakan petani, namun gerakan yang dibangun selama ini belum disertai dengan tuntutan perempuan atas hak untuk mengelola tanah secara independen, bahkan dalam gerakan yang diperjuangkan pun belum ada kesetaraan gender. Lebih lanjut, Agarwal (2008) menyatakan pada dasarnya dalam pandangan ilmu sosial mengenai bagaimana orang miskin dan tak berdaya menghadapi penindasan memiliki dua keyakinan yang berbeda. Selama ini mereka diberi persepsi palsu oleh ideologi penindas bahwa ketertindasan yang mereka alami 
akibat dari perilaku mereka sendiri. Ideologi penindas memberikan kesadaran palsu untuk menyembunyikan kepentingan ekonomi mereka yang sebenarnya.

Dalam Gender, Resistance and Land: Interlinked Struggles Over Resources and Meanings in South Asia (2008) Agarwal juga membahas mengenai sifat perlawanan perempuan, khususnya dalam konteks perjuangan mereka untuk hak tanah dan kesetaraan gender di Asia Selatan. la berpendapat bahwa persepsi perempuan tentang ketidakadilan gender tidak bisa dipahami hanya dengan mencari tindakan perlawanan yang terbuka, tetapi dengan dengan mempertimbangkan banyak cara terselubung dimana perempuan mengekspresikan ketidakpuasan mereka. Pada saat yang sama, tindakan rahasia (baik dilakukan secara individu atau dalam kelompok) tidak mungkin mengubah ketidaksetaraan dalam kekuasaan yang mendasari terjadinya opresi gender. Untuk mengubah ini cenderung membutuhkan resistensi dan perjuangan terbuka, dan tidak hanya dilakukan oleh perempuan secara individu tetapi oleh kelompok perempuan yang terorganisir. Meskipun perempuan petani di Asia Selatan telah memiliki sejarah panjang dalam perjuangan agraria, sampai saat ini mereka belum menegaskan klaim kebebasan mereka atas tanah yang diperjuangkan; mereka juga tidak terorganisir sebagai sebuah kelompok yang menuntut kesetaraan gender maupun terdaftar dalam organisasi maupun gerakan.

Masih dalam persoalan perempuan mempertahankan tanah mereka, Della Syahni dan Sapariah Saaturi (2017) mengenai gerakan perempuan Kendeng mempertahankan alam mereka dari pembangunan tambang. Para perempuan di Kendeng ini memperjuangkan tuntutan mereka agar pembangunan tambang di atas pegunungan karst segera dibatalkan. Mereka menuntut agar Gubernur Jawa Tengah mencabut izin pembangunan tambang dan polda mencabut status tersangka pada rekan mereka yang ditahan. Mereka melakukan cor semen pada kaki mereka sebagai bentuk perlawanan. Dalam keyakinan warga yang diwakili oleh para perempuan tersebut, operasi pabrik semen akan mengganggu CAT (cekungan air tanah) yang menjadi sandaran warga yang sebagian berprofesi sebagai petani untuk memenuhi kebutuhan hidup sehari-hari. Operasi pabrik semen diprediksi selanjutnya akan membatasi ruang hidup warga dan akan menyebabkan permasalahan sosial yang serius di masa depan.

\section{METODE PENELITIAN}

Penelitian ini menggunakan pendekatan kualitatif berperspektif feminis, yaitu mengelaborasikan sifat pendekatan kualitatif berupa eksplorasi, deskripsi, dan interpretasi dengan menelusuri pengalaman dan pengetahuan perempuan petani dalam mempertahankan ruang hidup dan sumber penghidupannya. Tipe penelitian ini menggunakan studi kasus yang menyebabkan peneliti mendapatkan gambaran utuh tentang berbagai fakta yang terjadi sekaligus keterhubungan dengan dimensi lain (Poerwandari, 2017). Pada penelitian ini, studi kasus yang diangkat adalah kompleksitas kehidupan perempuan petani dalam memperjuangkan ruang hidup dan sumber penghidupan mereka melalui lahan pertanian yang dirampas oleh PT. Pertamina Rosneft. Teknik pengambilan data yang saya gunakan adalah observasi, observasi terlibat, wawancara mendalam, focus group discussion, penelusuran sejarah kehidupan hingga studi dokumen. Subjek utama dalam penelitian ini adalah

a) Perempuan petani yang sumber penghidupannya hanya berasal dari lahan sumber pangan 
b) Perempuan petani yang mengerjakan lahan sendiri dengan tujuan untuk melihat bagaimana pola pengelolaan sumber pangan dan melihat relasi antara perempuan petani dengan sumber daya pangan (alam)

c) Perempuan petani pemilik maupun buruh yang melakukan perlawanan pasif maupun aktif. Perlawanan aktif disini yang mengikuti serangkaian acara demonstrasi atau protes dari awal hingga akhir. Perlawanan pasif berarti tidak ikut turun lapangan tetapi ikut memberikan dukungan berupa dana atau konsumsi untuk membantu kelangsungan acara

Penelitian ini dilakukan di Kabupaten Tuban. Lokasi pemilihan di Desa Sumurgeneng, Kecamatan Jenu, Kabupaten Tuban. Pemilihan Desa Sumurgeneng sebagai lokasi utama penelitian karena dari enam desa yang masuk dalam peta lokasi pembangunan, Desa Sumurgeneng merupakan desa yang paling banyak terdampak penggusuran lahan, tidak hanya lahan, tetapi area rumah mereka juga masuk dalam peta lokasi penggusuran. Durasi waktu dalam penelitian ini meliputi tahap persiapan, pelaksanaan penelitian di lapangan, pengolahan data dan penyusunan tesis. Lebih lanjut, untuk metode analisis data yang dikumpulkan pada penelitian ini meliputi data primer dan sekunder. Data primer diperoleh melalui observasi, observasi terlibat, wawancara mendalam, serta penelusuran sejarah kehidupan perempuan petani, sekaligus penelusuran riwayat keluarga untuk melihat bagaimana kesejarahan mengelola sumber penghidupan. Selanjutnya adalah isu etis, yaitu mengutamakan persetujuan subjek terlebih dahulu sebelum melakukan wawancara dengan menjaga kerahasiaan identitas subyek khususnya subjek utama, dengan cara menyamarkan nama asli mereka. Isu etis dalam penelitian ini bertujuan untuk menghormati hak pribadi dan memastikan subjek penelitian tidak dirugikan oleh pihak-pihak tertentu.

\section{HASIL DAN PEMBAHASAN \\ Perlawanan Perempuan Petani}

Persoalan perlawanan atas tanah yang melibatkan dinamika gender dan akses atas sumber daya telah terjadi di beberapa negara dan kota di Indonesia. Merujuk pada penelitian yang dilakukan oleh Shelly Grabe, Rose Grace Grose, dan Anjali Dutt pada 2014 di Tanzania dan Nikaragua yaitu Women's Land Ownership and Relationship Power: A Mixed Methods Approach to Understanding Structural Inequalities and Violence Against Women menghasilkan temuan bahwa ketika perempuan memiliki tanah, perempuan memiliki kuasa sedangkan ketika perempuan tidak memiliki tanah maka perempuan rentan mengalami kekerasan fisik dan psikis. Keterkaitan dari penelitian yang dilakukan oleh Shelly Grabe, Rose Grace Grose, dan Anjali Dutt dengan kutipan dari beberapa narasumber utama menjadi awal asumsi bahwa salah satu alasan yang menjadikan perempuan petani Sumurgeneng melakukan perlawanan adalah kekhawatiran mereka jika tidak memiliki tanah akan menempatkan mereka dalam situasi yang rentan, tidak hanya dalam situasi ekonomi tetapi juga rentan mengalami kekerasan fisik dan psikis. Melalui penelitian yang dilakukan oleh Nitya Rao dan Kumar Rana yang berjudul Land Rights and Women-Case of Santhals pada tahun 1997 didasari oleh pemikiran untuk memahami perempuan desa dan nilai hak atas tanah, penting untuk memahami karakter sosial pada relasi atas tanah dan properti, praktik legal dan ideologi yang berhubungan dengan struktur keluarga. Dengan demikian, merujuk pada dua artikel tersebut, perlawanan yang dilakukan oleh perempuan petani di Sumurgeneng tidak menutup kemungkinan adanya dorongan untuk mempertahankan hak akses dan 
kontrol mereka atas tanah pertanian. Selain itu mereka juga menyadari bahwa hak atas tanah bukan hanya berpengaruh pada kontrol atas tanah namun juga berpengaruh dalam aspek sosial, budaya, dan ekonomi yakni melawan kemiskinan, menghilangkan opresi yang dilakukan oleh laki-laki dan tindakan kekerasan dalam rumah tangga, memperbaiki distribusi sumber daya pada rumah tangga, teknologi, informasi, dan pelayanan lain. Lebih lanjut, isu hak atas tanah dan aset produktif merupakan konstruksi sosial dan menjadi indikator pada relasi kuasa bukan hanya menyangkut soal kelas namun juga dimensi gender.

Perempuan petani memiliki peran ganda dalam rumah tangga, sebagai penyedia makanan, kenyamanan serta pengasuh keluarga. Selain itu, mereka juga dituntut untuk tetap berkontribusi dalam pertanian. Mulai dari tahap menanam, memanen, hingga pada distribusi produknya. Namun peran perempuan seringkali tidak dianggap sebagai kunci keberhasilan dalam pengelolaan dan peningkatan produksi pertanian. Hal ini disebabkan karena peran perempuan petani yang terkucilkan dan keterbatasan mereka dalam melakukan akses dan kontrol terhadap sumber daya. Mereka terlempar dari proses pengambilan keputusan dan tidak diikutsertakan dalam pendistribusian hasil pertanian. Sehingga mereka dianggap tidak berkontribusi secara penuh, meskipun pada dasarnya tahapan demi tahapan dalam mengelola lahan telah dilakukan oleh perempuan.

Perlawanan petani perempuan Sumurgeneng memiliki kemiripan dengan perlawanan perempuan yang ditulis oleh Miranda Morgan yaitu Women, Gender and Protest: Contesting Oil Palm Plantation Expansion in Indonesia, menyatakan para pengunjuk rasa perempuan mengidentifikasi berbagai kemungkinan dampak dari perampasan tanah, baik material maupun tidak berwujud, yang mendasari keputusan mereka menolak ekspansi kelapa sawit di desa mereka. Karena peran dan tanggung jawab gender yang dominan dalam rumah tangga dan masyarakat, perempuan cenderung lebih menderita akibat dampak pengembangan minyak sawit di masa depan. Hilangnya tanah dan tempat tinggal mereka, hilangnya tanaman yang ada, ancaman reproduksi, kerawanan pangan, kesempatan kerja terbatas hingga perubahan budaya di masyarakat.

Perempuan dituntut tidak hanya waspada terhadap risiko yang terkait dengan pengembangan kelapa sawit, tetapi juga kelangsungan hidup keluarga mereka. Seperti yang telah dicatat dalam (Beckwith 1996; Corcoran-Nantes 1993; Silvey 2003) perempuan pengunjuk rasa dalam kasus ini memanfaatkan peran gender mereka dalam masyarakat sebagai ibu dan nenek untuk melegitimasi kekhawatiran tentang masa depan keluarga mereka dan masyarakat karena ekspansi kelapa sawit dan dengan demikian membenarkan keputusan mereka untuk protes. Hal tersebut juga dialami oleh perempuan petani di Sumurgeneng, salah satu anggota perlawanan perempuan, Mulan dalam wawancaranya menyatakan kekhawatirannya tentang kelangsungan hidupnya tanpa tanah.

“Kabeh warga kerjo mbak, sakmeniko dadi tani, yung-yung'e yo kerjo. Onok sing dadi rewang, tur ono sing nduwe sawah dewe. Sekabeh'e kerjo. Mengko tanah iki nek dijupuk, sak derek'e kabeh kerjo opo? Urip'e mengko kepriye? Senajan mung tandur tapi sederek kabeh iki seneng, cukup lan ayem." 
(Warga disini semuanya kerja Mbak, jadi petani. Ibuk-Ibuknya juga kerja. Ada yang buruh tani, ada yang punya tanah sendiri, semuanya bekerja. Nanti kalau tanah ini diambil, kami kerja apa? Hidup kami bagaimana? Walaupun bertani tapi kami tercukupi dan nyaman)

(Mulan (nama samaran), 32 tahun, penggagas gerakan perempuan tani dan kordinator lapangan aksi menolak kilang minyak Tuban)

Mulan lahir, besar dan tinggal di Desa Sumurgeneng.. Kegiatan sehari-harinya mengajar di Madrasah sembari mengelola tanahnya. Saat tidak ada jadwal mengajar, Mulan ikut mengelola sawah bersama saudaranya. Dalam wawancaranya, Mulan menceritakan bagaimana dirinya menikmati profesinya sebagai petani. Baginya menjadi petani tidak hanya melanjutkan profesi turun-temurun dari keluarga, melainkan sebagai identitas dan ruang hidupnya.

"Bapak Ibuk tani Mbak, Iha kalau gak dikelola, mau diapain? Dijual ya eman, wong ini warisan keluarga. Tanah Sumurgeneng subur, setahun bisa tiga kali panen. Ya rugi kalau dijual. Enak jadi tani aja Mbak, jadwal semuanya kita yang ngurus. Berangkat, pulang sesuka hati. Nikmat sekali bertani itu" (Mulan, 32 Tahun)

Identitas sebagai petani itulah yang mendasari Mulan untuk tergabung dalam gerakan perlawanan petani Sumurgeneng, Tuban Darurat Agraria. Baginya warisan keluarga keharusan untuk dilestarikan. Mulan sebenarnya adalah pertama dari dua bersaudara. Mulan memiliki adik yang berusia tiga tahun lebih muda darinya. Sama seperti dirinya, adik Mulan juga bekerja sebagai petani. Bagi keluarga Mulan, pertanian telah menjadi bagian dari kehidupan mereka, sekaligus menjadi penopang hidup.

Perlawanan perempuan di desa Sumurgeneng cukup unik. Mereka bukan satusatunya perlawanan yang ada di Sumurgeneng, tetapi mereka mengambil andil penting dalam perlawanan dengan membentuk asosiasi perempuan tani tolak kilang, terutama dalam memobilisasi massa dan aksi. Secara umum petani di desa Sumurgeneng menyatakan adanya asosiasi perempuan tani tolak kilang telah mempermudah gerak protes mereka. Respon para aparat ketika menghadapi demonstran perempuan akan sangat berbeda ketika berhadapan dengan demonstran laki-laki. Mereka menganggap pihak aparat sedikit lebih tenang ketika menghadapi perempuan petani. Bagi mereka itu adalah keuntungan. Morgan (2017) justru mengkritik adanya mobilisasi peran gender. Baginya dengan memilih untuk memobilisasi peran gender tersebut berisiko memperkuat posisi gender yang tidak setara yang sering kali mengecualikan mereka dari politik di tempat pertama. Para perempuan di Sambas berpartisipasi dalam aksi tetapi mereka tidak diikutsertakan dalam pengaturan strategi dan pengambilan keputusan. Morgan menyebut peristiwa tersebut tersebut sebagai perpanjangan relasi gender yang tidak setara, tetapi dengan jelas menempatkan kelompok perempuan ini untuk melakukan protes di Sambas hanya sebagai seorang partisipan tanpa wewenang, dan bagi Morgan selalu ada potensi perjuangan gender yang tidak setara, tetapi dibalut seolah perjuangan tersebut merupakan perjuangan gender yang adil.

Perlawanan perempuan petani di Sumurgeneng memiliki keunikan sendiri. Mereka terbagi dalam beberapa tugas. Perlawanan mereka memang tidak terpisah dari perlawanan laki-laki, namun mereka memiliki peran penting yang menjadi bagian dari ciri khas perlawanan, seperti menempatkan perempuan dalam garda depan dan berhadapan langsung dengan pihak aparat. Hal ini setali tiga uang dengan perlawanan yang ada di Kamboja yang dilakukan oleh V. Lamb, L. Schoenberger, C. Middleton 
(2017) dalam Gendered Eviction, Protest and Recovery: A Feminist Political Ecology Engagement with Land Grabbing in Rural Cambodia menyatakan perlawanan yang terjadi di Kamboja menitikberatkan pada aksi protes perempuan. Setelah konflik yang berujung penggusuran dan pembakaran pada Maret 2013 dan kemudian pada April 2014, masyarakat turun ke jalan-jalan Phnom Penh menuntut pertanggungjawaban dari Gubernur setempat. Terdapat pembagian peran dalam aksi perlawanan yang dilakukan oleh korban. Srey, seorang lbu juga salah satu pemimpin aksi berbicara tentang pembagian peran laki-laki dan perempuan. Srey menjelaskan mengapa perempuan lebih banyak diturunkan ke jalan, salah satunya karena perempuan dianggap lebih emosional. Mereka dapat menangis, berteriak, menunjukkan kesulitan yang mereka hadapi lebih baik daripada laki-laki. Lebih lanjut Srey menjelaskan bahwa pihak berwenang kurang memperhatikan atau mengambil tindakan dalam menanggapi perempuan, sehingga hal ini dipandang mengurangi kemungkinan terjadinya kekerasan. Penempatan perempuan di garis depan ini dinilai strategis. Mengingat bagaimana lakilaki diwaspadai dan rentan mengakibatkan timbulnya provokasi berujung kekerasan. Oleh sebab itu dalam aksi protes yang terjadi di Kamboja, perempuan terus memainkan peran yang lebih besar dalam protes publik, terutama karena diperlukan pertemuan dan negosiasi dengan pasukan keamanan negara. Selain itu, Srey menegaskan kembali dampak penggusuran dan perampasan tanah dirasakan secara berbeda oleh laki-laki dan perempuan.

Warga menyadari misi ini bukannya tanpa risiko. Mereka melakukan perjalanan protes ke Phnom Penh juga mengharuskan mereka untuk menata ulang pekerjaan rumah tangga dan mata pencaharian seluruh keluarga. Dalam wawancaranya (V. Lamb, L. Schoenberger, C. Middleton, 2017) dengan perempuan dan keluarga yang berpartisipasi dalam protes, mereka menceritakan berbagai macam perjuangan yang dihadapi oleh seluruh keluarga untuk dapat berpartisipasi. Para keluarga harus mengatur dan mengkoordinasikan kegiatan mereka dalam waktu yang lama termasuk pembagian kerja berdasarkan gender dalam rumah tangga. Hal serupa juga diakui oleh Aritonang, petani laki-laki yang ikut berpartisipasi aktif dalam aksi ini mengakui peran perempuan petani dalam aksi sangat signifikan, terutama dalam menghadapi aparat.

"Kalau aparat itu ndak berani Mbak sama demonstran perempuan. Jadi kalau orasi itu bisa terdengar dengan baik. Keluh kesahnya bisa tersampaikan. Kalau demonstran laki-laki ya langsung ricuh karena sama-sama emosi. Kalau diskusi atau negosiasi ya ini ketuanya laki-laki." (Aritonang, 42 Tahun, petani Sumurgeneng).

Penuturan Aritonang secara tidak langsung turut menyatakan bahwa mobilisasi peran gender dianggap sebagai sesuatu yang umum di Indonesia, dimana mereka menempatkan demonstran perempuan untuk menunjukkan sisi afeksi dalam gerakan aksi. Di Kamboja, salah satu peserta protes, bernama Kunthea menceritakan dirinya telah tinggal di Khsem sejak 2009, dan bekerja di perkebunan karet, berpenghasilan 20.000 riel atau lima dolar per hari. Kunthea, sebagai seorang ibu dari sebuah keluarga beranggotakan empat orang, bermigrasi dari Kampong Cham dimana dia dan suaminya tidak memiliki tanah apapun. Kunthea datang ke daerah tersebut untuk bekerja di perkebunan, dan setibanya di sana mencari nafkah dengan memanfaatkan hasil hutan, mengumpulkan kayu dan produk lain dari hutan. Keluarganya mendirikan sebidang tanah sekitar dua hektar tempat ia dan suaminya bekerja bersama-sama menanam 
jagung dan singkong. Setelah penggusuran, keluarga Kunthea memutuskan untuk berpartisipasi dalam protes di Phnom Penh, tetapi untuk melakukannya Kunthea dan suaminya harus berbagi tanggung jawab menjaga dan menitipkan anak, salah satunya dengan mengirim putri mereka ke kampung asal mereka, Cham. Dalam hal ini penulis menyoroti adanya peran gender yang dinegosiasikan untuk pembagian peran lain.

Baik Miranda Morgan (2017) maupun V. Lamb, L. Schoenberger, C. Middleton (2017) menyatakan adanya perlawanan ini bukanlah tanpa sebab, para perempuan selain kehilangan mata pencaharian dan sumber penghidupan. Mereka juga harus menanggung beban keluarga untuk menghindari dari kerawanan pangan. Dalam sebuah aksi protes perempuan yang terjadi di Kalimantan, Sumurgeneng maupun di Kamboja, para perempuan dipilih untuk menjadi garis depan perlawanan karena sikap petugas yang berbeda. Perempuan dianggap lebih mampu secara emosional dan dapat berteriak kencang kepada pihak berwenang. Tetapi pada saat yang sama, strategi yang dilakukan oleh pengunjuk rasa di Kamboja dan Sumurgeneng ini dapat memperkuat hierarki yang telah ditetapkan di mana perempuan sering diabaikan dalam perwakilan politik dan pengambilan keputusan. Melihat kasus perlawanan atas perampasan tanah, memposisikan perempuan di garis depan dapat berisiko memperkuat hubungan gender yang tidak setara. Morgan (2017) menyatakan bahwa kondisi peluang ikut serta dalam proses politik yang bergender seperti ini akan merugikan perempuan. Terlebih tidak dilibatkannya perempuan dalam proses perlawanan yang informal.

Morgan (2017) juga menjelaskan bagaimana peran gender tradisional masih berlaku dalam serangkaian protes yang dilakukan. Sebagai contoh, perempuan dianggap memiliki hambatan terhadap proses politik formal karena tingkat pendidikan dan melek huruf yang rendah. Mereka menilai, protes cenderung memakan waktu lebih sedikit sehingga perempuan tidak harus mengorbankan atau mengkompromikan tanggung jawab rumah tangga mereka kepada laki-laki. Dalam hal ini dapat terlihat bahwa penempatan perempuan di publik dalam aksi bukan karena pembagian peran yang adil melainkan sebagai sebagai kekuatan untuk mengikis bahaya. Hal ini memperkuat adanya gender otoritas yang tidak seimbang dan garis hierarkis yang masih tinggi serta semakin tertutupnya peluang untuk pemberdayaan atau kesetaraan perempuan.

\section{Tanah Sebagai Sumber Penghidupan}

Bagi para perempuan petani, tanah memiliki makna mendalam yang berkaitan dengan kelangsungan hidup mereka. Selama bertahun-tahun, mereka menggantungkan hidup dengan mengelola tanah, sebagai petani maupun buruh tani. Tanah yang ditanami, dirawat hingga panen dan menjadi sumber penghasilan bagi keluarga. Walaupun bagi buruh tani, hasil panen bukan untuk mereka sepenuhnya, tetapi jerih payah yang dikeluarkan untuk menghasilkan padi, jagung dan tanaman lainnya telah membantu mereka untuk menyambung hidup. Ada tiga hal penting yang dapat mendefinisikan bagaimana makna tanah bagi perempuan petani di Sumurgeneng.

Makna tanah secara ekonomi, bagi perempuan Sumurgeneng, tanah adalah identitas mereka. Melalui tanah, mereka mendefinisikan diri mereka sebagai seorang petani, mengelola lahan dan memanfaatkan hasil pertanian untuk menghidupi kebutuhan sehari-hari. Makna tanah secara sosial, Tanah tidak hanya memberikan manfaat untuk perseorangan, tetapi juga untuk masyarakat secara umum. Tanah dapat dimaknai secara sosial untuk berbagi dengan sesama atau kepada orang yang 
membutuhkan. Seperti pada penuturan subyek Bu Marisa, dalam mengelola hasil panennya tidak menjual sepenuhnya kepada tengkulak, tetapi menyisihkan juga untuk dibeli oleh warga desa dengan harga yang lebih murah. Jika menggunakan prinsip ekonomi, maka keputusan Bu Marisa dan suaminya ini merupakan kerugian, tetapi jika melihat dari aspek berbagi, maka tindakan Bu Marisa dan suami ini merupakan makna tanah secara sosial yang berarti memberikan sedekah dan berbagi kepada sesama warga desa.

"Yo mesakke Mbak, nek tukune ning pasar. Regane luwih larang. Adoh pisan. Iki yo tetep oleh untung, nanging yo ora okeh. Nek karo wong kulak yo iso sewu rong ewu untunge, tapi nek karo wong buroh yo kur limang atus iku wes cukup. Yo karo tonggo dewe dilarangi yo saru. Wong awakdewe iki syukur mampu. Mosok yo ora mesakke."(Bu Marisa, petani pemilik)

(Ya kasihan mbak kalau belinya di pasar. Harganya lebih mahal. Jauh pula. Ini ya tetap dapat untung, tapi ya tidak banyak. Kalau dengan tengkulak ya bisa untung seribu dua ribu, tapi kalau dengan buruh tani ya lima ratus saja cukup. Ya dengan tetangga sendiri kalau mahal ya tidak bagus. Kita ini syukur mampu, masa ya tidak kasihan.)

Prinsip berbagi yang dimiliki Bu Marisa ini sebenarnya tidak hanya dilakukan oleh Bu Marisa saja, tetapi sudah menjadi bagian dari warga Desa Sumurgeneng.

Bertani memiliki makna yang lebih dalam daripada sekedar mengelola tanah. Pada dasarnya bertani atau bercocok tanam telah ada di Indoeseia sejak lama. Dalam bertani, terdapat prinsip gotong royong yang menjadi identitas masyarakat Indonesia sejak dahulu. Umumnya, gotong royong dalam bertani akan terlihat pada masa nandur atau awal menanam benih. Masyarakat secara gotong-royong akan saling membantu. Begitu pula dengan perempuan petani di Sumurgeneng, ikatan antar sesama petani akan semakin tampak saat masa tanam tiba. Tanah memiliki makna yang mendalam bagi perempuan petani di Sumurgeneng. Mereka memiliki nilai ekonomi dan sosial yang tidak dapat dipisahkan dari kehidupan sehari-hari.

Makna tanah secara budaya, Tanah secara budaya juga memiliki makna tersendiri bagi masyarakat Desa Sumurgeneng. Salah satunya berkaitan dengan tradisi yang dilakukan menjelang panen. Menurut penuturan Bu Marisa, petani Sumurgeneng ketika melakukan panen, akan melakukan berbagai tradisi lebih dulu. Diawali dengan tradisi wiwitan yaitu dilakukan sebelum panen padi dengan tujuan sebagai ungkapan balas budi dan rasa syukur petani karena telah diberikan hasil panen yang melimpah.

"Iku nek mongso panen podo wiwitan sek. Iku mono gawe rasa syukur ben panen e lancar. Wiwit iku gowo panganan banca'an neng sawah trus terus dungo bareng supoyo berkah. Anane panganan sing digawe wiwit iku yo dipangan karo wong sing melu manen sawah iki. Yo sing mreman, yo sing nduwe podo mangan kabeh." (Bu Marisa, Januari 2020)

(Itu kalau mau panen melaksanakan wiwitan dulu sebagai bentuk syukur petani karena diberikan hasil panen yang melimpah. Wiwit itu bawa makanan ke sawah lalu berdoa bersama agar berkah. Adanya makanan yang dibawa untuk wiwit ini ya dimakan oleh orang-orang yang ikut memanen ini. Ya yang ikut buruh tani, yang punya ikut makan semua)

Tradisi wiwitan rutin dilakukan sebelum melakukan panen karena diyakini akan membawa berkah bagi masa panen berikuttnya. Dalam wiwitan, pelaksanaannya dilakukan secara terperinci. Ada hitungan hari Jawa atau weton untuk menentukan kapan wiwitan itu dilaksanakan. Masyarakat setempat menyebutnya dengan pon, wage, 
kliwon, legi, pahing, dengan pilihan utama Rabu pon atau Sabtu legi. Pemilihan hari tersebut tidak terlepas dari keyakinan yang dianut masyarakat bahwa hari yang baik akan menghasilkan panen yang baik pula.

Uraian dalam wawancara diatas menjadi petunjuk bahwa tradisi wiwitan memiliki nilai -nilai budaya yang luhur. Wiwitan tidak hanya sekedar membagi makanan tetapi juga ada nilai yang terkadung dari segi lingkungan, sosial, dan spiritual. Lingkungan sebagai tempat tinggal manusia memiliki peran utama dalam pemenuhan segala kebutuhan hidup manusia baik dalam hal kehidupan dan penghidupan. Tradisi wiwitan memberikan makna positif untuk menghormati alam dan menjaga alam agar tetap lestari. Makna sosial dalam wiwitan tercermin pada sikap peduli dan saling berbagi. Kesederhanaan dalam wiwitan telah mempererat ikatan para petani. Lebih lanjut, nilai spiritual dari tradisi wiwitan adalah wujud rasa syukur kepada Tuhan atas segala nikmat dan rezeki yang diberikan.

Perempuan petani Sumurgeneng memaknai tanah dibentuk oleh pengetahuan dan pengalaman sejak kecil yang secara terus-menerus diperkenalkan oleh orangtua dan lingkungannya. Sehingga memahami bahwa tanah memiliki nilai secara ekonomi sebagai sumber penghidupan dan tabungan ketika ada kebutuhan mendesak. Makna sosial sebagai tempat untuk berbagi pada orang lain (sedekah) dan budaya yaitu tradisi menjelang masa panen dan dilakukan secara turun-temurun. Menurut Elmhirst (2011) dalam ekologi politik feminis menyebut bahwa perempuan memiliki kepentingan terdiferensiasi gender dalam lingkungan dan sumber daya alam sesuai peran, tanggung jawab, dan pengetahuan yang dimilikinya. Berkaitan dengan peran produktif, sejak kecil perempuan petani di Sumurgeneng diberikan peran dan tanggung jawab untuk mengurus tanaman terutama di sawah. Bagi yang tidak memiliki tanah pun, sejak kecil perempuan turut membantu orang tuanya yang bekerja sebagai kuli atau buruh tani. Dengan demikian, pengetahuan yang terbentuk pun berkaitan dengan peran dan tanggung jawabnya tersebut.

\section{Perampasan Tanah dan Perjuangan Kesetaraan Gender}

Telah banyak literatur yang membahas mengenai partisipasi perempuan dalam protes massa, tetapi belum ditemukan yang secara spesifik membahas perlawanan perempuan sebagai gerakan yang independen. Seperti yang diungkapkan oleh Morgan (2017) dalam Women, Gender and Protest: Contesting Oil Palm Plantation Expansion in Indonesia perlawanan perempuan hanya digambarkan dengan cara mendukung suami mereka untuk berpartisipasi dalam aksi sekaligus untuk menyembunyikan suami mereka saat berhadapan dengan polisi. Morgan (2017) mengungkapkan para petani perempuan menggunakan identitas mereka sebagai petani lokal untuk membenarkan keputusan melakukan aksi protes. Mereka juga memanfaatkan posisi gender di masyarakat untuk melegitimasi kekhawatiran mengenai masa depan keluarga karena pengembangan kelapa sawit. Adanya perluasan lahan produksi kelapa sawit akan memberikan konsekuensi yang signifikan di masyarakat, terutama semakin memperburuk ketidaksetaraan gender.

Studi yang dilakukan Morgan (2017) mengungkapkan aksi protes yang dilakukan perempuan tidak tepat disebut sebagai tindakan politik, karena tindakan politik seperti ini lebih banyak dikuasai dan didominasi oleh laki-laki. Lebih lanjut, laki-laki juga yang menentukan bagaimana perempuan akan berpartisipasi. Selain itu dalam pengambilan keputusan formal maupun informal terkait dengan kelapa sawit, baik mengenai 
keberlanjutan konsesi kelapa sawit maupun aksi protes, perempuan juga tidak banyak dilibatkan.

Morgan (2017) juga menyebut politik informal tidak boleh dianggap sebagai solusi untuk memfasilitasi keterlibatan perempuan dalam politik. Memberikan ruang bagi perempuan untuk terlibat dalam hal-hal formal tidak dapat dilihat hanya melalui keikutsertaan perempuan dalam unjuk rasa tanpa mengetahui bagaimana prosesproses yang telah dialami perempuan. Selama ini perempuan telah banyak terpinggirkan dan tersubordinasi dalam ruang publik, sehingga menyebut perempuan telah diberikan wadah untuk kesetaraan gender dengan melakukan aksi protes sangatlah tidak tepat. Terkait aksi ini, perempuan Sambas mengakui dalam posisi sulit untuk memutuskan. Bukan karena penolakan dari dalam diri mereka sendiri, melainkan tindakan yang dilakukan oleh orang-orang (laki-laki) yang terlibat unjuk rasa tersebut dapat membuka atau menutup kemungkinan untuk perempuan untuk berpartisipasi.

Singkatnya, studi kasus ini telah menunjukkan berbagai relasi gender yang mempengaruhi keputusan perempuan untuk berpartisipasi dalam aksi protes (dengan menunjukkan tujuan dan peluang politik mereka). Meskipun relasi gender yang dominan cenderung mengecualikan perempuan dari urusan publik dan politik formal di Sambas, tetapi fakta bahwa perempuan ikut serta dalam aksi protes adalah tanda bahwa peran, harapan, dan norma gender yang konservatif sedang mengalami perubahan.

Penelitian ini telah menunjukkan bahwa relasi gender yang timpang membuat perempuan terlibat dalam aksi protes bukan melalui kesadaran dan keputusan mereka sendiri, sekaligus menunjukkan bahwa relasi gender tidak datang tiba-tiba tetapi dibangun secara sosial dan dengan demikian terus dinegosiasikan. Lebih lanjut, studi kasus ini mengungkapkan bagaimana perjuangan perempuan desa melawan perampasan tanah juga tidak terlepas dari perjuangan mereka memperjuangkan kesetaraan gender.

\section{KESIMPULAN}

Pembangunan kilang minyak yang dilakukan dengan pengambilalihan lahan pertanian telah memaksa petani kehilangan penghidupannya (livelihood) dan memposisikan perempuan menjadi kelompok rentan karena mata pencahariannya dengan mengelola lahan pertanian tergantingan dengan aktivitas pertambangan kilang minyak. Alasan perempuan petani dan buruh tani di Sumurgeneng menolak sangat jelas, karena ijin yang diberikan kepada pihak PT. Pertamina Rosneft tidak melibatkan warga, terutama perempuan dan tidak melalui tahapan yang semestinya. Kemarahan warga desa Sumurgeneng melahirkan gerakan perlawanan, termasuk melahirkan aliansi perempuan petani tolak kilang. Penolakan perempuan petani ini sebagai bentuk perlawan terhadap tindakan-tindakan sepihak Pertamina. Metode perjuangan gerakan aliansi khusus ini menggunakan dua strategi, yaitu melalui aksi protes berupa demonstrasi dan mengajukan gugatan ke Pengadilan Tata Usaha Negara. Aksi demonstrasi inilah yang menjadi salah satu kekuatan penolakan yang dilakukan oleh para petani Sumurgeneng.

Bagi perempuan petani, mereka mempertahankan tanah mereka karena bagi mereka tanah-tanah memiliki makna secara ekonomi, sosial dan budaya. Secara ekonomi, tanah merupakan tempat mereka bekerja mencari nafkah untuk keluarga. Tanah bagi perempuan-perempuan petani memberi makna sebagai sumber penghidupan. Di masa depan tanah juga dimaknai sebagai tabungan ketika ada 
kebutuhan keluarga yang mendesak seperti biaya pendidikan, biaya kesehatan, dan keperluan mendesak lainnya. Secara sosial, tanah bermakna bahwa hasil tanaman digunakan sebagai media berbagi pada tetangga atau orang lain yang membutuhkan. Sedangkan makna tanah secara budaya, dimaknai dengan adanya tradisi budaya yang diterapkan dalam bertani yakni aturan dalam bertani dan tradisi bertani alami yang dipelajari secara turun-temurun sebagai bagian dari identitas mereka.

Ruang dan wilayah merupakan bagian penting dalam kehidupan petani. Jika ruang dan wilayah merupakan bagian penting dalam kehidupan perempuan, saat wilayah di mana perempuan bergantung hidup dirampas untuk dieksploitasi alamnya dan atau dihancurkan untuk diubah kegunaannya, perempuan akan menghadapi berbagai bentuk ketidakadilan, termasuk ketidakadilan gender, dan berbagai masalah lain yang muncul akibat kerusakan sosio-ekologis yang terjadi. Selain itu, dampak yang berlanjut adalah kemiskinan berkepanjangan. Dengan demikian, perempuan yang dirampas dan atau dihancurkan wilayah tempat ia bergantung hidup tidak hanya kehilangan tanah dan wilayah tetapi lebih jauh lagi ia kehilangan ruang hidupnya

\section{DAFTAR PUSTAKA}

Agarwal, B. (2008). Gender, Resistance and Land: Interlinked Struggles Over Resources and Meaning in South Asia. The Journal of Peasant Studies, 22(1). https://doi.org/10.1080/03066159408438567

Elmhirst, R. (2011). Introducing New Feminist Political Ecologies. Journal of Geoforum, 42(2), 129-132. https://doi.org/10.1016/j.geoforum.2011.01.006

Fringka, Y. (2015). Resistensi Berbasis Adat: Perlawanan Masyarakat Nagari III Koto, Tanah Datar, Sumatera Barat, Terhadap Pembangunan Bukit Batubasi. MASYARAKAT, Jurnal Sosiologi, 21(2). https://doi.org/10.7454/mjs.v21i2.4670

Habibie, M. (2016). Surplus Pekerja Di Kapitalisme Pinggiran. Prisma Resource Center.

Kurniawan, A. H. (2013). Persistensi dan Resistensi Masyarakat Terhadap Eksistensi Pertambangan Emas di Desa Bonto Katute,Kabupaten Sinjai. FISIP Universitas Hasanudin.

Morgan, M. (2017). Women, gender and protest: contesting oil palm plantation expansion in Indonesia. The Journal of Peasant Studies, 44(6), 1177-1196. https://doi.org/10.1080/03066150.2017.1300579

Poerwandari, K. (2017). Pendekatan Kualitatif Untuk Penelitian Perilaku Manusia. LPSP3 UI Fakultas Psikologi Universitas Indonesia.

Prayogo, D. (2008). Konflik Antara Korporasi dengan Komunitas Lokal: Sebuah Kasus Empirik Pada Industri Geotermal di Jawa Barat (5th ed.). FISIP UI Press.

Regus, M. (2008). Tambang dan Perlawanan Rakyat: Studi Kasus: Tambang di Manggarai, Nusa Tenggara Timur. MASYARAKAT: Jurnal Sosiologi, 16(1). https://doi.org/10.7454/mjs.v16i1.4879 